\title{
Living Better with SCD
}

\author{
Safaa Eldeeb* \\ Pediatrician, Jeddah, KSA \\ *Corresponding Author: Safaa Eldeeb, Pediatrician, Jeddah, KSA.
}

Received: January 27, 2021

Published: February 25, 2021

(C) All rights are reserved by Safaa Eldeeb.
Your child can live a full, active life when he/she have sickle cell disease. They can participate in most of the similar activities as others. Making smart selections is essential in maintaining the condition from flare up into a crisis.

Sickle cell disease (SCD) is a hereditary condition in which the structure of red blood cells is abnormal and its shape is like $\mathrm{C}$ letter that can get trapped in blood vessels and block them. This obstruction is termed a painful crisis or sickle crisis.

You will not have total control over how SCD alters their body. But they can take steps to cope with pain and to lessen chances of problems.

\section{Helping things}

Sickle cell disease is a complicated disease, so it is crucial to visit the doctor for routine health checkups, to help in reducing the number of troubles that may need emergent medical referral. There are some methods to be careful of:

- Drink a lot of fluids: Dehydration can increase the hazard of a sickle crisis, so get enough amount of water.

- Sleep: Getting enough sleep would help.

- Eat healthy: Eating fruits, vegetables, whole grains are very important.

- Exercise: Being active can help reduce the risk of the crisis.

- Take Up to date vaccines: It is significantly important to get all routine vaccines, including the yearly flu shot, pneumococcal and meningococcal vaccines. Common infections, like the common cold, can become hazardous if there is SCD.
Harming things

- Extreme hot or cold temperature: Any swift changes in temperature, could trigger a crisis.

- High altitude: Shortage of oxygen at high altitudes could cause a crisis. (Airplanes, because they are pressurized, would not be a trouble).

- Smoking: This can produce a lung condition known as acute chest syndrome. This is once sickle cells stick all together and prevent oxygen from getting inside the lungs.

- Contaminations and infections: Common sicknesses can be very dangerous for those with SCD. Washing hands prior to eating or after using the toilet.

- Stress: It is difficult to avoid, but stressful state can initiate a crisis, so try to find time to rest or learn practices that help your child calm down.

- Intense physical effort: Though it is good to get reasonable exercise, very severe activities that are tiring should be prevented.

How to help your child?

If your child has Sickle cell disease, you need to support them to enjoy a normal life. There are methods that you can offer support:

- Identify indicators of crisis: You could be capable to know when your child is about to have a crisis. Understanding the signs can help you cope with crises rapidly or possibly prevent them from occurring again.

- Offer a support system: Be aware of symptoms, be arranged, and make grants when necessary when SCD impacts 
appear.

- Assist with pain relief: Take an effective role in alleviating pain. This could mean giving a massage, getting a heat pad, or using compresses. You may help your child with breathing exercises or other techniques to enable them to relax.

- Reach out to support services: Parents of children with SCD have support groups that you may think about joining. There are also social workers and mental health clinicians that can help families deal with the diagnosis.

- Keep your child's teachers informed: Make sure that schoolteachers, day-care personnel and other people who are assigned to your child's nursing know why they may need more numerous water breaks, toilet breaks. The CDC has published a booklet for teachers on how to help students who have sickle cell disease.

When to get medical aid

Be aware of potential complications caused by SCD. If your child has any of the following, get medical care immediately:

- Fever of 38 or greater

- Pain in the chest

- Acute pain

- Headache, unsteadiness or stiff neck

- Attack of seizure

- Swelling in abdomen

- Loss of sensation or movement

- Difficult breathing

- Problems in vision [1-6].

\section{Bibliography}

1. https://www.webmd.com/a-to-z-guides/living-with-sicklecell\#3

2. https://www.cdc.gov/ncbddd/sicklecell/healthyliving-livingwell.html

3. https://www.ncbi.nlm.nih.gov/pmc/articles/PMC2730199/

4. Sickle Cell Disease Association of America, Inc. (SCDAA) (2012).

5. Current Guidelines for Sickle Cell Disease Management of Acute Complications.
6. U.S. Department of Health and Human Services, National Institutes of Health, National Heart Lung and Blood Institute. The management of sickle cell disease. Fourth edition, revised June, 2002. NIH Publication No. 02-2117. (Clinical Guideline) (2012).

\section{Assets from publication with us}

- Prompt Acknowledgement after receiving the article

- Thorough Double blinded peer review

- Rapid Publication

- Issue of Publication Certificate

- High visibility of your Published work

Website: www.actascientific.com/

Submit Article: www.actascientific.com/submission.php Email us: editor@actascientific.com

Contact us: +919182824667 